\title{
(Re)Application of the Radio in Scientific Education and Teacher Training
}

\author{
Luciano Gonsalves Costa1*, Marcelo Alves Barros'2, Anair Altoé3, \\ Aldevino Ribeiro da Silva ${ }^{3}$, Heliana da Silva ${ }^{4}$ \\ ${ }^{1}$ Professional Master Program in Physics Teaching, Physics Department, State University of Maringá (UEM), \\ Maringá, Brazil \\ ${ }^{2}$ São Carlos Institute of Physics, University of São Paulo, São Carlos, Brazil \\ ${ }^{3}$ Department of Theory and Practice of Education, State University of Maringá (UEM), Maringá, Brazil \\ ${ }^{4}$ Laboratory for Educational Support, State University of Maringá (UEM), Maringá, Brazil \\ Email: ${ }^{*}$ luciano@dfi.uem.br
}

Received 19 May 2014; revised 24 June 2014; accepted 8 July 2014

Copyright (C) 2014 by authors and Scientific Research Publishing Inc.

This work is licensed under the Creative Commons Attribution International License (CC BY).

http://creativecommons.org/licenses/by/4.0/

c) (i) Open Access

\section{Abstract}

In this paper, we describe aspects of the "Media in the Service of Education" project which was implemented based in two (sub) projects "Physics for Everyone: Science Education on the Radio" and "Education News on the Radio". The project "Physics for Everyone: Science Education on the Radio" proposed to disseminate science education by radio to the public least served by the Internet, and the proposed project "Education News on the Radio" is to share with serving teachers successful experiences of coping with difficulties in learning and performance in the field of exact and natural sciences. In this perspective, the "Media in the Service of Education" project aims to disseminate initiatives to improve the quality ("best practices") of the teaching of exact and natural sciences, covering municipalities located within a radius of $150 \mathrm{~km}$ around Maringá (Paraná State, Brazil), comprising the Metropolitan Region of Maringá and northwest of Paraná State (Brazil). By way of illustration, in "Education News on the Radio," using the signal of Radio UEM FM, the project's activities of target Paraná municipalities with a low human development index (HDI).

\section{Keywords}

Science Education on the Radio, In-Service Training on the Radio, Teaching of Exact and Natural Sciences

${ }^{*}$ Corresponding author. 


\section{Introduction}

Despite the rapid evolution observed in the development of information and communication technologies (ICTs) from the second half of last century, access to new ICTs (computer, internet, digital TV, etc.) is currently very limited in Brazil.

According to the National Research by Household Sample (PNAD) of the National Institute of Geography and Statistics (IBGE), 2009 (Brazil, 2010b), only 34.7\% of households have computers and 27.4\% of households have computers with internet access. Furthermore, according to this survey, $64.6 \%$ of the population aged 10 or older does not use the Internet.

Moreover, PNAD-2009 (Brazil, 2010b) indicates that radio is present in 87.9\% of Brazilian homes (television, in $95.7 \%$ of households), which guarantees the national broadcasting network wide geographical coverage and greater social penetration. Furthermore, compared to the computer with Internet, the low cost of a radio makes it more affordable to the general population.

Other data on the presence of radio in Brazil (Dados, 2011): cars: 83\% of vehicles have radios; regions: in the North the radio is present in 78.6\% of households, in the Northeast in 81.8\%, in the Center-West in 88.0\%, 94.7\% in the Southeast and in the South, $96.0 \%$; gender: $90 \%$ of the female population and $91 \%$ of the male population regularly listen to the radio, age range: $92 \%$ of the population 10 - 14 years (13\% of the national population) regularly listens to the radio, 97\% of 15 - 19 years (12\% of the national population), 95\% of 20 - 29 years (24\% of the national population), $91 \%$ of 30 - 39 years (21\% of the national population), $87 \%$ of $40-49$ years (13\% of the national population), $84 \%$ of 50 - 64 years (12\% of the national population) and $74 \%$ of the over 65 years (5\% of the national population); economic class: $93 \%$ of Class A1 (2\% of the national population) regularly listens to the radio, $91 \%$ of A2 (6\% of the national population), $90 \%$ of B1 (13\% of national population), $91 \%$ of B2 (15\% of the national population), 91\% of C (36\% of the national population), $89 \%$ of D (24\% of the national population) and $84 \%$ of $\mathrm{E}$ (4\% of the national population).

On the educational level, the Brazilian experience with education via the radio may be considered to have been a success, especially between 1920 and 1970. Different initiatives contributed to this, such as the founding of the Radio Society of Rio de Janeiro in 1923, the creation of the Educational Broadcasting Service of the Ministry of Education-MEC in 1937, the launching of the University of the Air project by the National Commercial Apprenticeship Service-Senac in 1950, the organization of the Basic Education Movement-MEB in 1959, the proposal of the Brazilian Literacy Movement-MOBRAL in 1967, and the implementation of the Minerva Project in 1970 .

However, for reasons of a political-ideological nature associated with the military government scheme introduced in the country in the 1970s (Alves, 2009), Brazilian educational radio lost its voice from that time and only in the last decade has it once again begun to attract educational interest due to the number of advantages previously mentioned.

Below, we describe two projects of this nature in development at the State University of Maringá (UEM): one of them started in 2011 and another in 2013.

\subsection{Physics for Everyone: Science Education on the Radio}

Objectives:

- To broadcast science education via radio, especially for the public least served by the Internet;

- To provide students with supplementary educational content, teachers with in-service training, and scientific information aimed at the general population;

- To stimulate the general public's interest in scientific activity. Methodological aspects:

- Transmission of education-oriented/educational programs at times compatible with target audience’s availability;

- Use features of radio language (sound effects, drama, interview) as a strategy to create attractive programs;

- Adaptation of the content to suit the target audience from an informational, educational and entertainment perspective;

- Use of illustrative examples based on everyday situations to encourage the assimilation of the concepts covered. 
Pedagogical guidance:

- Education with an emphasis on content (basic idea: use the radio to transmit knowledge) (KAPLAN cited Del Bianco, 2009: p. 58).

Instructional Resources:

- Parts of the radio project "Physics Access", available at http://201.55.67.236/acessa_fisica/index.php/acessafisica. Implementation:

- Transmission of the following audio units from "Physics Access": 1) Electrostatics: lightning and electrical shock; 2) Centripetal Force: “Mexican Hat”; 3) Quantities: systems of units; 4) Gravity: tidal phenomena; 5) Innovation; and 6) Electromagnetic Waves: the cell phone.

- Period from 17 to 23 October 2011 (National Week of Science and Technology).

- Location: State University of Maringá (Brazil), UEM Radio 106.9 FM, Maringá, Paraná State, Brazil.

\subsection{Education News on the Radio}

General objectives:

- To provide teachers working in elementary education with updates on methodology;

- To contribute to improving the quality of basic teaching of exact and natural sciences;

- To link educational research and extension in solving problems of elementary education;

- To disseminate innovative teaching methodologies in exact and natural sciences;

- The acquisition of national equipment (didactic modules) for demonstration of laboratory science practice, for the second phase of the project.

Specific Objectives:

- To systematize the results of educational research on the problems existing in the teaching of exact and natural sciences in Brazil;

- To diagnose the real scientific, technological or teacher training needs of teachers in the exact sciences and natural sciences in the school network of the Metropolitan Region of Maringá and Northwest of Paraná (Brazil);

- To produce radio content for the training of teachers in the exact sciences and natural sciences employed in the school network of the Metropolitan Region of Maringá and Northwest of Paraná (Brazil);

- To disseminate, via radio, successful experiences ("best practices") in the solution of educational problems in the field of exact and natural sciences;

- To set up the infrastructure for a multiuser teaching laboratory to train teachers in teaching experimental science, in the next phase of this project.

Methodology:

The methods and techniques involved include literature review, documentation research, documentation analysis, questionnaires, the production and broadcast of radio content and the dissemination of project results.

The starting point of data collection is the literature and documentation, and a questionnaire circulated to teachers employed by the school network in the Metropolitan Region of Maringá and Northwest of Paraná (Brazil) to diagnose their immediate training needs.

The planning of the questionnaire references records of educational research and empirical evidence from the school routine. And the respondents are attached to municipalities located within a radius of $150 \mathrm{~km}$ around Maringá, which represents the catchment area of FM Radio UEM signal.

"How to support teachers in addressing the issues that directly affect their work and the school's performance results?”, "In terms of professional development, what are their real most pressing needs?” and "How to foster methodological improvement at a fast pace and on a large scale?” are examples of questions of interest to the project.

The review of the literature and documentation will allow the identification of techniques, methodologies or innovative projects aimed at the improvement of school education in general. Once the work of collecting data and the processing and analysis of it has been concluded, production will begin on radiophonic content for the dissemination of successful experiences in the approach to educational problems in the area of exact sciences and natural sciences that were cataloged.

Finally, the results of the project have been published in articles or other forms of scientific communication. 


\section{Some Considerations}

In Brazil, from the introduction of schooling in 1549 until the present day, the teaching of exact and natural sciences (Physics, Mathematics, Chemistry, Biology and Sciences) has been characterized by the lecture method, dependence on the book, absence of experimentation, outdated curriculum, low number of lessons, and inadequate teacher professionalization (Pedrisa, 2001; Diogo \& Gobara, 2007) which, in turn, has constituted a barrier to educational and school learning attainment, with a negative impact on the understanding and interest in science.

Currently, discussions on contemporary issues in basic education are guided by the systematic observation of everyday school life. In particular, a general review of the present situation: 1) highlights the urgency of promoting an education that supports the rapid acceleration of the production of scientific knowledge and an understanding of the contemporary technological and productive matrix (Costa, 2004); 2) indicates the need to reformulate teaching with a view to increasing the inclusion of people with special needs into mainstream education; and 3) reveals the limited presence of information and communication technologies (ICT) in teaching practice due to the lack of ICT skills combined with an ignorance of the pedagogical potential of these technologies on the part of the teacher (Fregoneis, Altoé, Costa, \& Silva, 2011), which counter the availability of ICT infrastructure in most of the country's schools ${ }^{1}$.

In this context, the 1st edition of the "Physics for Everyone: Science Education on the Radio" project was broadcasted from 18 to 23 October 2011 by Radio FM UEM during the National Week of Science and Technology (SNCT). The main purpose of it is to motivate the public on science and technology themes and activities. On this occasion, sketches from the "Physics Access" project, combining sound effects, drama, humor, interviews and recurring themes in the presentation of physics topics were transmitted; this edition of the project broached the following topics: "Electrostatics: Lightning and Electric Shock", "Centripetal Force: Mexican Hat", "Quantities: Unit Systems”, "Gravity: Tidal Phenomena”, "Innovation” and "Electromagnetic Waves: Cell Phone”.

The inauguration of this project "Physics for Everyone: Science Education on the Radio" was greeted with a positive acceptance of both the format and the purpose of the project.

In terms of the scientific and technological contributions of the "Education News on the Radio" project, the expectation is that the project will impact on the production of knowledge on the training of teachers and didactic innovation as well as the production of content/audio units to train teachers in-service in the area of exact and natural sciences, in addition to the creation of the infrastructure of a multiuser didactic laboratory for didactic science experimentation.

From the point of view of the socio-economic impact, there are prospects for a contribution to improving the quality of elementary education, the in-service updating of teachers on teaching methodologies on a large scale, the training of human resources for educational research and the social integration of educational research.

The target audience of this project are the teachers of elementary education in the school system of the Metropolitan Region of Maringá and Northwest of Paraná (Brazil), municipalities within 150 km around Maringá within range of the signal of Radio UEM 106.9 FM, comprising at least 30 municipalities of low HDI.

On the level of results, the expectation is that the activities of these projects will have a positive impact on the educational context of their development, contributing to:

- Integration of EMU with the schools in the Northwest of Paraná;

- The broadcasting of content/audio units on successful experiences ("best practices") in addressing educational problems in the field of exact and natural sciences;

- Qualitative improvement in the pedagogical practice of teaching exact and natural sciences;

- The creation of the infrastructure for a multiuser didactic laboratory for the teaching of scientific experimentation at EMU, to train teachers in teaching science experimentation, in the next phase of "Education News on the Radio".

It is pertinent to underline our concern regarding:

1) Issues of accessibility: The radio's lack of visual dimension is not a complete disadvantage; psychological studies show that sound perception enables the creation of visual-acoustic representations on the part of the re-

\footnotetext{
${ }^{1}$ According to the Ministry of Education’s (MEC) Basic Education School Census 2010 (Brazil, 2010a), which considered both the public and private sectors, in 2010, out of a total of 38.6 million elementary and high school students in Brazil, $70 \%$ (27 million students) attended schools with no science lab, 39\% (15 million) were studying in establishments without libraries, 35\% (14 million) were enrolled in schools without sports facilities, and 24\% (9.5 million) in establishments without a computer lab.
} 
ceiver, and negative effects resulting from aural impairment can be reduced by compensatory sensory stimulation.

2) Potential disadvantages: Linearity of the transmission (propagation and temporal sequential transmission: ephemeral and successive); (space-time transmission: instantaneous and simultaneous); and the unidirectionality of transmission (reduced interactivity with expansion related to the use of other communication resources at set times).

\section{Acknowledgements}

We thank SETI-PR (Program USF) for the financial support of these studies.

\section{References}

Alves, J. R. M. (2009). Ch. 2: A história da EAD no Brasil. In F. M. Litto, \& M. Formiga (Eds.), Educação a distância: O estado da arte (pp. 9-13). São Paulo: Pearson.

Brasil (2010a). Censo escolar da educação básica de 2010. Brasília: MEC/Inep. http://www.inep.gov.br/basica/censo/default.asp

Brasil (2010b). Instituto Brasileiro de Geografia e Estatística. Pesquisa nacional por amostra de domicílios: Síntese de indicadores 2009. Rio de Janeiro: IBGE. http://www.ibge.gov.br/home/estatistica/populacao/trabalhoerendimento/pnad2009/comentarios2009.pdf

Costa, L. G. (2004). Apropriação tecnológica e ensino: As tecnologias de informação e comunicação e o ensino de física para pessoas com deficiência visual. Ph.D. Thesis, Porto Alegre: Universidade Federal do Rio Grande do Sul.

Dados sobre o rádio no Brasil (2011). http://www.microfone.jor.br/saiba.htm

Del Bianco, N. R. (2009). Ch. 9: Aprendizagem por rádio. In F. M. Litto, \& M. Formiga, (Eds.), Educação a distância: O estado da arte (pp. 56-64). São Paulo: Pearson.

Diogo, R. C., \& Gobara, S. T. (2007). Sociedade, educação e ensino de física no Brasil: Do Brasil Colônia ao fim da era Vargas. Proceedings from Simpósio Nacional de Ensino de Física, São Luis, 17.

Fregoneis, J. G. P., Altoé, A., Costa, L. G., \& Silva, A. R. (2011). Uso da tecnologia computacional na educação: Competências e atitudes de professores. Inovação e Tecnologia, 1, 11-17.

Pedrisa, C. M. (2001). Características históricas do ensino de ciências. Ciência \& Ensino, 11, 9-12. 
Scientific Research Publishing (SCIRP) is one of the largest Open Access journal publishers. It is currently publishing more than 200 open access, online, peer-reviewed journals covering a wide range of academic disciplines. SCIRP serves the worldwide academic communities and contributes to the progress and application of science with its publication.

Other selected journals from SCIRP are listed as below. Submit your manuscript to us via either submit@scirp.org or Online Submission Portal.
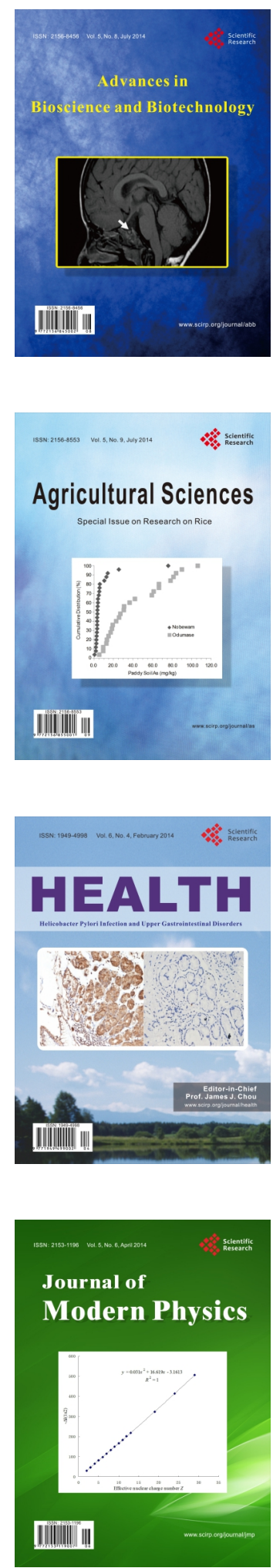
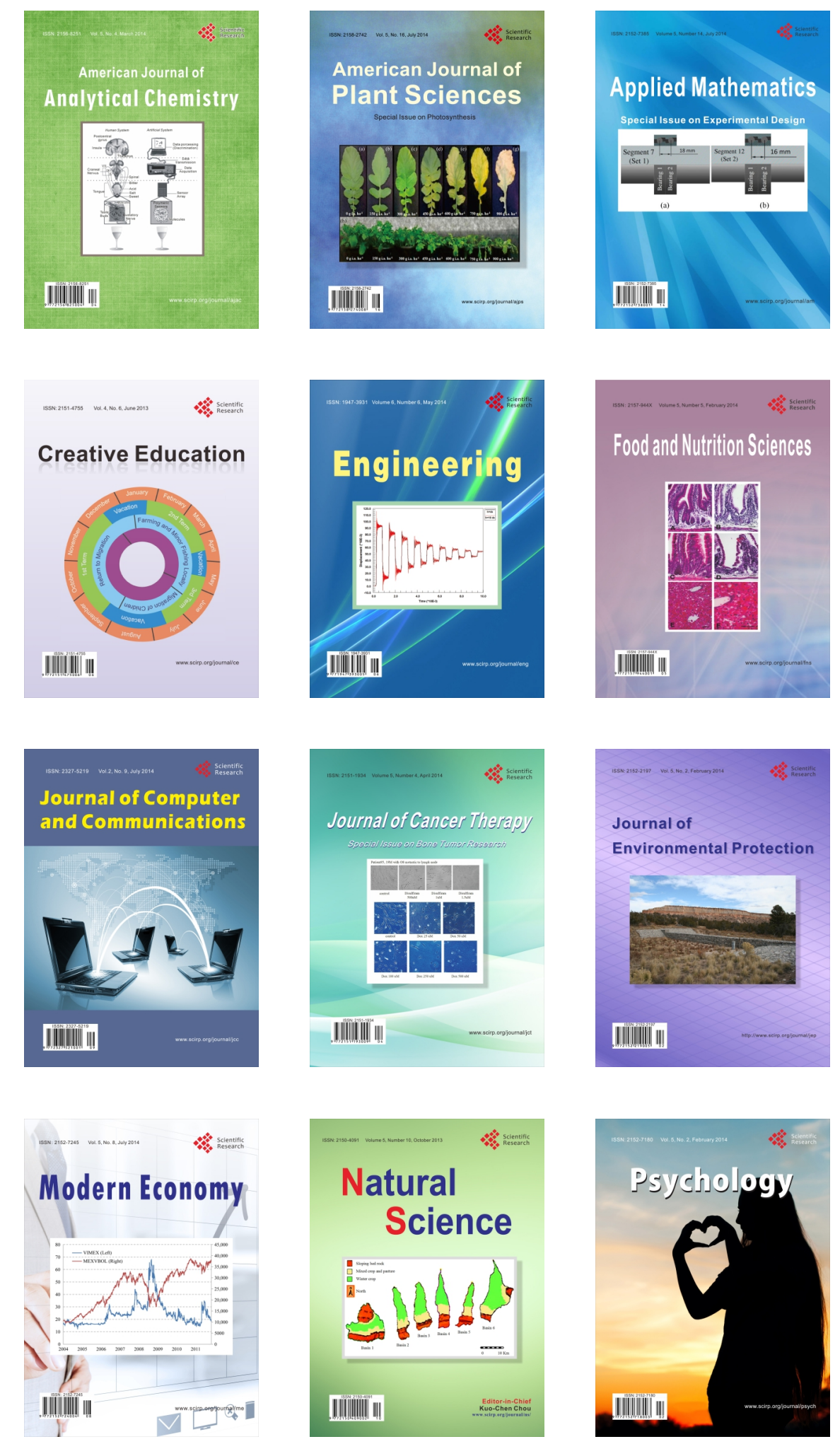